\title{
Intramammary challenge of lipopolysaccharide stimulates secretion of lingual antimicrobial peptide into milk of dairy cows
}

\author{
N. Isobe, ${ }^{* 1}$ K. Morimoto, $†$ J. Nakamura, ${ }^{*}$ A. Yamasaki, ${ }^{*}$ and Y. Yoshimura* \\ *Graduate School of Biosphere Science, Hiroshima University, Higashi-Hiroshima 739-8528, Japan \\ †Livestock Technology Research Center, Hiroshima Prefectural Technology Research Institute, Shobara 727-0023, Japan
}

\begin{abstract}
Lingual antimicrobial peptide (LAP) belongs to the $\beta$-defensin family in cattle and is found in bovine milk. However, it is unclear whether LAP is involved in the early immune response to mammary infection. The aim of the study was to investigate the changes of LAP concentration in milk after intramammary challenge with lipopolysaccharide (LPS), the gram-negative bacteria cell membrane component, in dairy cows. Milk was collected before and after LPS or phosphate-buffered saline (control) challenge every hour for $12 \mathrm{~h}$ on $\mathrm{d} 0$ and twice daily from d 1 to 7 . Somatic cell count (SCC), LAP concentration, and lactoperoxidase (LPO) activity in the milk were measured. Somatic cell count started to increase at $2 \mathrm{~h}$ postchallenge and remained high until d $5\left(694 \pm 187 \times 10^{3}\right.$ to $>1,000 \pm 0 \times 10^{3}$ cells $/ \mathrm{mL}$ at d $0 ;>1,000 \pm 0 \times 10^{3}$ cells $/ \mathrm{mL}$ at $\mathrm{d} 1$ to $3 ; 684 \pm 194$ $\times 10^{3}$ to $829 \pm 108 \times 10^{3}$ cells $/ \mathrm{mL}$ at d $4 ; 527 \pm 197 \times$ $10^{3}$ to $656 \pm 145 \times 10^{3}$ cells $/ \mathrm{mL}$ at d 5 ). Somatic cell count increased in the control cows, although the levels were lower compared with those in the LPS challenge group. The LAP concentration in milk increased significantly at $2 \mathrm{~h}$ post-LPS-challenge and was maintained at high levels until d $2(8.6 \pm 0.6$ to $17.5 \pm 2.3 \mathrm{n} M)$. In the control cow infused with phosphate-buffered saline, there was no increase of LAP concentration in milk (5.1 \pm 0.6 to $7.2 \pm 0.8 \mathrm{nM}$ ). Increase of LPO activity in the milk was observed at $6 \mathrm{~h}$ after LPS challenge and continued until d $3(4.7 \pm 0.3$ to $9.4 \pm 1.1 \mathrm{U})$. No increase of LPO activity was observed in the milk of control cows. The increase and subsequent decrease in LAP concentration after LPS challenge occurred earlier than those of LPO activity. In multiparous cows with LPS infusion, there was a significantly negative relationship between the days leading to the basal levels in LAP concentration and LPO activity $(\mathrm{r}=-0.75)$. These
\end{abstract}

Received July 28, 2009.

Accepted September 17, 2009.

${ }^{1}$ Corresponding author: niso@hiroshima-u.ac.jp results suggest that LPS induces secretion of LAP into milk within hours and that LPO may have a synergistic antimicrobial function with LAP in mammary glands of dairy cows.

Key words: lingual antimicrobial peptide, milk, dairy cow, lipopolysaccharide

\section{INTRODUCTION}

Defensin is one of the many antimicrobial peptides that is cationic and amphiphilic, having tridisulfide bonds, and it is found in a variety of animals (Ganz, 2003; Subedi et al., 2008). Defensin plays a crucial role in the innate immunity system: it causes permeabilization of target bacterial membranes, resulting in cell lysis and eventual bacterial death (Ganz, 2003). Both gram-negative and gram-positive bacteria can be targeted by defensin (Schonwetter et al., 1995). The bovine $\beta$-defensin family includes lingual antimicrobial peptide (LAP; Schonwetter et al., 1995), bovine neutrophil $\beta$-defensin (Selsted et al., 1993; Goldammer et al., 2004), tracheal antimicrobial peptide (Diamond et al., 1991), and enteric $\beta$-defensin (Tarver et al., 1998). The expression of LAP mRNA was reported in the mammary glands of cows (Swanson et al., 2004). Immunohistochemical studies demonstrated the expression of LAP in the alveolar epithelium of mammary glands (Petzl et al., 2008; Isobe et al., 2009b). Furthermore, Isobe et al. (2009a) found that LAP was secreted into bovine milk.

Lactoperoxidase (LPO) in bovine milk catalyzes the inactivation of a wide range of microorganisms in the LPO system (Fweja et al., 2007). Lactoperoxidase catalyzes, in the presence of hydrogen peroxide, the oxidation of $\mathrm{SCN}^{-}$(thiocyanate) to yield $\mathrm{OSCN}^{-}$(hypothiocyanite) and HOSCN (hypothiocyanous acid; Shin et al., 2001 ) and the oxidation of $\mathrm{I}^{-}$to yield $\mathrm{OI}^{-}$(hypoiodite) and HOI (hypoiodous acid; Bosch et al., 2000). These compounds react with microbial sulfhydryl groups to inhibit various cellular functions (Shin et al., 2001). Lactoperoxidase activity in milk was reported during the dry period (Marshall et al., 1986) and throughout lactation (Fonteh et al., 2002) in dairy cows. 
Mastitis, the critical infectious disease of the mammary gland of dairy cows, induces various immune responses. Intramammary infection increased the expression of LAP mRNA as determined by both reverse transcription-PCR and in situ hybridization (Swanson et al., 2004). An immunohistological study demonstrated an increased localization of LAP in Escherichia coli-inoculated alveoli in the inoculated mammary gland compared with the healthy ones (Petzl et al., 2008). Yet, the precise time course of LAP expression after bacterial infection is unknown in dairy cows. Lingual antimicrobial peptide synthesized in the alveolar epithelial cells is secreted into the milk (Isobe et al., 2009a). As bacterial infection increased the expression of LAP in epithelial cells, the LAP concentration in the milk was elevated by the infection. Furthermore, Seifu et al. (2007) measured LPO activity and SCC in goat milk and found a close relationship between them, although knowledge on changes in LPO activity after inflammation in cows is limited. Therefore, this study was undertaken to investigate changes in LAP concentration in bovine milk after LPS challenge and to explore the relationship between the functions of LAP and LPO in the mammary innate immunity system.

\section{MATERIALS AND METHODS}

\section{LPS Administration and Milk Sample Collection}

Holstein-Friesian dairy cows $(\mathrm{n}=17$, parity $=1$ to 3, 9 nulliparous and 8 multiparous cows) were used. One cow was at 95 DIM and others were at later stages of lactation. Cows with low SCC $(<100,000$ cells $/ \mathrm{mL})$ were used. The cows at Livestock Technology Research Center, Hiroshima Prefectural Technology Research Institute (Shobara, Japan) were fed in accordance with the regulations of Hiroshima University for animal experiments.

Lipopolysaccharide stock solution $(1.0 \mathrm{mg} / \mathrm{mL})$ was prepared by dissolving LPS (from E. coli O111:B4; Wako Pure Chemical Industries, Osaka, Japan) in PBS. One mammary gland was infused with LPS at a dose of $0.1 \mathrm{mg} / 10 \mathrm{~mL}$ in 12 cows and with $10 \mathrm{~mL}$ of PBS in 4 other cows. In 1 cow, 2 quarters were used, one for LPS infusion and the other for PBS.

From the onset to $12 \mathrm{~h}$ after infusion, milk was collected by hand every hour. The day of infusion was considered as d 0. Thereafter, twice daily (at 0900 and $1600 \mathrm{~h}$ ) from d 1 to 7 , milk was collected using a machine. Milk samples were divided into 2 parts; the first part was spread on a glass slide for SCC following the Breed method (Schalm et al., 1971). The second sample of milk was stored at $-30^{\circ} \mathrm{C}$ until measurement of LAP concentration and LPO activity.

\section{Measurement of LAP Concentration}

Milk fat was removed by centrifugation at $1,700 \times$ $g$ for 30 min at $4^{\circ} \mathrm{C}$, with the resulting skim milk used for enzyme immunoassay performed as described previously (Isobe et al., 2009b) with minor modifications. A 96-well microtiter plate was coated with $2 \mu \mathrm{g} / \mathrm{mL}$ anti-LAP antibody in carbonate buffer $(\mathrm{pH} 9.7)$ at $4^{\circ} \mathrm{C}$ overnight; this was followed by blocking with $0.05 \mathrm{M}$ borate buffer supplemented with $0.2 \%$ BSA at $\mathrm{pH} 7.8$. Skim milk samples were diluted 10 times with borate buffer. Afterward, $0.05 \mathrm{~mL}$ of diluted skim milk or LAP standard (11 synthesized peptides; Isobe et al., $2009 \mathrm{~b}$ ) and $0.05 \mathrm{~mL}$ of horseradish peroxidase-labeled LAP (Isobe et al., 2009b) were pipetted into wells followed by incubation for $3 \mathrm{~h}$ at room temperature. After washing 4 times with PBS, the wells were incubated with $0.15 \mathrm{~mL}$ of tetramethyl benzidine (TMB) solution for $30 \mathrm{~min}$. The optical density was measured at $655 \mathrm{~nm}$ wavelength. Assays were performed in duplicate. Sensitivity and recovery of LAP were $0.04 \mathrm{nM}$ and 100 to $115 \%$, respectively. Coefficients of variation for intra- and interassay variation were 6.5 and $13.5 \%$, respectively.

\section{Measurement of LPO Activity}

Milk LPO activity was determined as described by Wijkstrom-Frei et al. (2003). Defatted milk was mixed with TMB solution as described above and incubated at $37^{\circ} \mathrm{C}$ for $30 \mathrm{~min}$. After brief centrifugation at $6,000 \times$ $g$ for 1 min, the optical density of supernatant was measured at $655 \mathrm{~nm}$. Lactoperoxidase (Sigma, St. Louis, $\mathrm{MO})$ at a concentration of 0 to $10 \mathrm{U}$ was used as a standard. (One unit formed $1 \mathrm{mg}$ of purpurogallin from pyrogallol in $20 \mathrm{~s}$ at $\mathrm{pH} 6.0$ at $20^{\circ} \mathrm{C}$.)

\section{Statistical Analysis}

Differences in LAP concentrations, LPO activity between $0 \mathrm{~h}$ and other timed samples, and differences in times of increase and decrease among SCC, LAP, and LPO were analyzed by Student's $t$-test. Correlation analysis was carried out using Pearson correlation analysis among increase and subsequent decreases of SCC, LAP, and LPO followed by analysis for significance of correlation coefficient by Student's $t$-test. A probability of $<0.05$ was considered significant.

\section{RESULTS}

At $2 \mathrm{~h}$ after LPS treatment, SCC increased to more than $500 \times 10^{3}$ cells $/ \mathrm{mL}$, which was significantly higher than that observed at $0 \mathrm{~h}$ (Figure 1). Significantly high- 


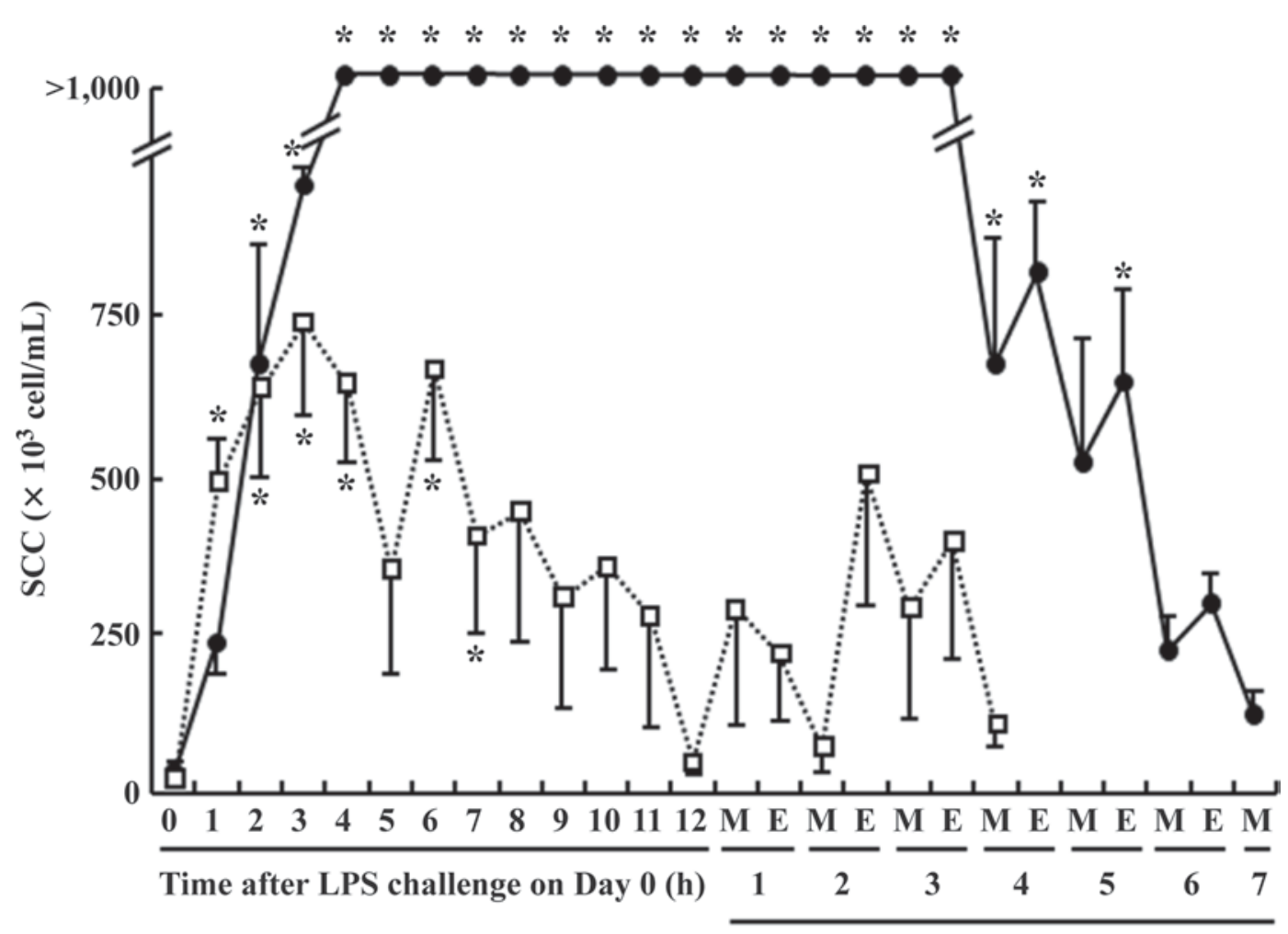

Day after LPS challenge

Figure 1. Somatic cell count after LPS $(\bullet)$ or PBS $(\square)$ infusion in dairy cows. Values are expressed as mean \pm SEM (n $=13$ for LPS and 5 for PBS). ${ }^{*}$ Indicates that concentrations are higher $(P<0.05)$ than that before LPS infusion. $\mathrm{M}=$ morning; $\mathrm{E}=$ evening.

er concentrations were maintained until d 5 . In the case of PBS infusion for controls, SCC increased gradually from 1 to $7 \mathrm{~h}$ after infusion. Afterward, SCC decreased below $500 \times 10^{3}$ cells $/ \mathrm{mL}$.

The concentration of LAP in milk was approximately $6.6 \mathrm{n} M$ before LPS infusion, whereas the concentration was elevated significantly at $2 \mathrm{~h}$ after infusion to more than $10 \mathrm{n} M$ (Figure 2). From $2 \mathrm{~h}$ on d 0 to $\mathrm{d} 2$, LAP concentrations were significantly higher than that before infusion. There was an abrupt but short-lived decrease at $6 \mathrm{~h}$ on $\mathrm{d} 0$, although the concentration was higher than that before infusion. There was no increase in the LAP concentration in the milk of cows infused with PBS.

Lactoperoxidase activity after LPS infusion is shown in Figure 3. From 0 to 5 h, LPO activity was at basal levels but increased significantly thereafter compared with values before infusion. Higher activities were maintained until d 3. Infusion of PBS into mammary gland caused no significant increase in LPO activity.

To compare the changes in SCC, LAP concentration, and LPO activity in milk, the time when SCC values increased to $500 \times 10^{3}$ cell $/ \mathrm{mL}$, LAP to $10 \mathrm{n} M$, or LPO to $5 \mathrm{U}$ for the first time were calculated and shown in Table 1. The values of $10 \mathrm{n} M$ (LAP) or $5 \mathrm{U}$
(LPO) were based on the significantly different values compared with those determined before LPS challenge in Figures 2 and 3. Increases in SCC and LAP were similar, whereas the increase of LPO activity occurred significantly later than those of SCC and LAP. Similarly, the subsequent decrease in LPO was significantly later than that of LAP.

Relationships of changes in the SCC, LAP concentration, and LPO activity in milk were examined. In all cows, time for the increase of SCC was significantly positively correlated to LPO activity $(\mathrm{r}=0.59)$. Only in multiparous cows was there a significant high negative relationship between the decreased time in LAP concentration and LPO activity $(\mathrm{r}=-0.75)$ and significant high positive relationship between increased time in LPO activity and SCC $(\mathrm{r}=0.69)$

\section{DISCUSSION}

The concentration of LAP in milk was increased up to 4-fold by the LPS challenge. Intramammary infusion of PBS did not affect LAP concentration in milk. These results suggest that LPS infusion induced LAP secretion into milk in dairy cows. Lingual antimicrobial peptide mRNA (Swanson et al., 2004) and protein (Isobe 


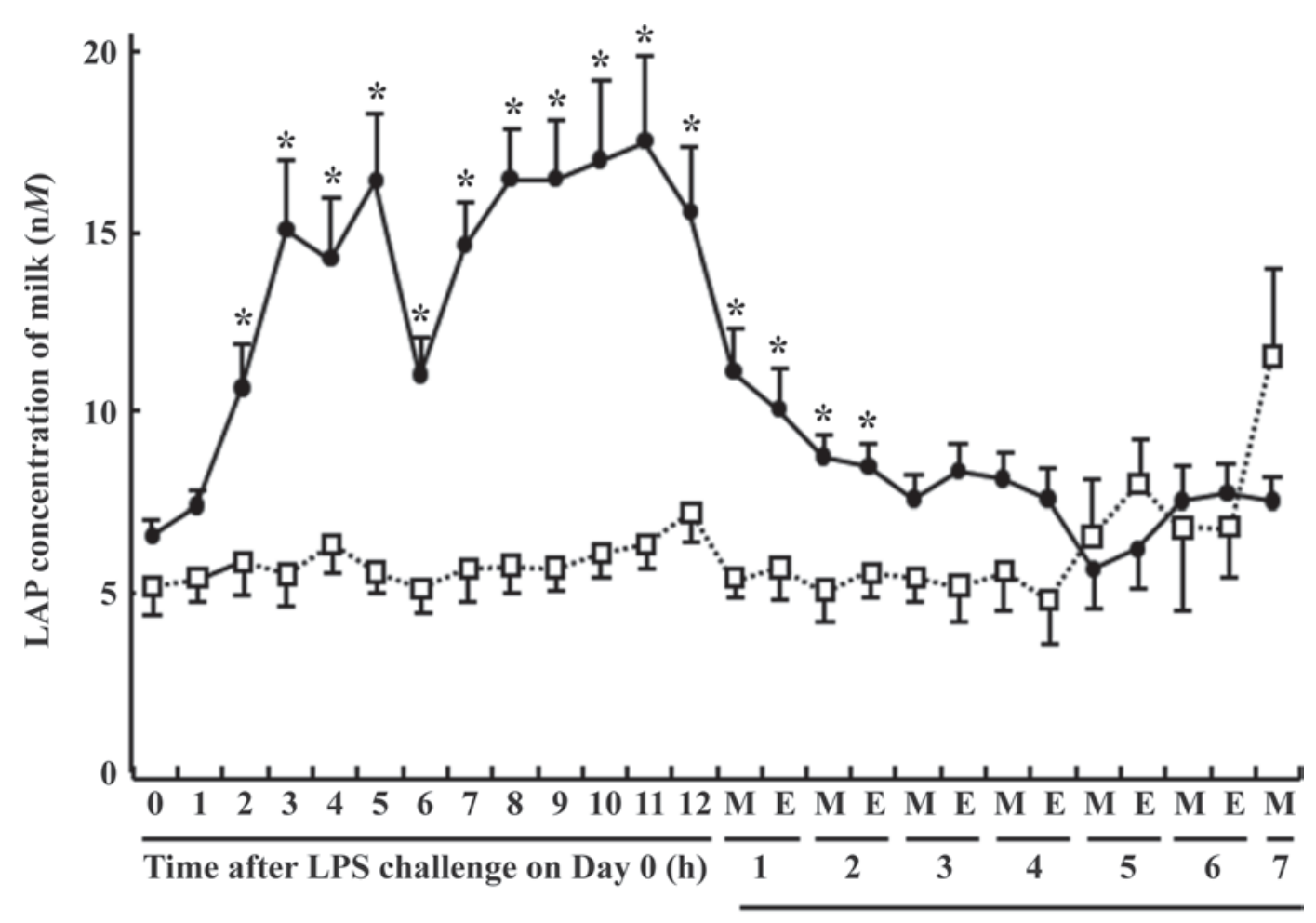

Day after LPS challenge

Figure 2. Lingual antimicrobial peptide (LAP) concentration in milk after LPS $(\bullet)$ or PBS ( $\square$ ) infusion in dairy cows. Values are expressed as mean \pm SEM $\left(n=13\right.$ for LPS and 5 for PBS). ${ }^{*}$ Indicates that concentrations are higher $(P<0.05)$ than that before LPS infusion. M $=$ morning; $\mathrm{E}=$ evening.

et al., 2009b) were localized in the epithelial cells of the alveoli in mammary glands. This suggests that LAP was secreted from the alveolar epithelium. Lipopolysaccharide is detected by toll-like receptor 4 (TLR4), causing cell signaling for the immune response leading to secretion of defensin (Hoshino et al., 1999). Alveolar epithelium in the mammary gland expresses TLR4 (Goldammer et al., 2004). Therefore, LPS-stimulated secretion of LAP is probably associated with TLR4 in the alveolar epithelial cell in mammary glands of dairy cows.

After LAP concentration increased, it then decreased to the basal level within $2 \mathrm{~d}$. Lingual antimicrobial peptide, one of the members of the $\beta$-defensin family, is involved in the innate immune system that is responsible for the early stages of immunity, which may explain why LAP concentration was reduced within $1 \mathrm{~d}$. Moreover, in the present study, the LPS challenge was at one concentration only. Therefore, it is necessary to examine whether LPS challenge of higher amounts and multiple introductions may cause extended durations of high LAP concentration in milk. In addition, LPS (not bacteria) was used to induce the immunoreactions in the present study, which might be one of several reasons why the LAP concentration decreased early.
Although LAP concentration declined on d 2, SCC remained elevated until d 5. Somatic cell counts contain mainly leukocytes and a small number of alveolar epithelial cells. Lingual antimicrobial peptide and leucocytes are both members of the innate immunity system. These show that LAP plays a crucial role only in the early stages of innate immunity and that leukocyte recruitment continues for a longer time beyond that of LAP.

Lactoperoxidase activity in milk increased significantly starting at $6 \mathrm{~h}$ after LPS infusion and was main-

Table 1. Characteristics of changes of SCC, lingual antimicrobial peptide (LAP) concentration, and lactoperoxidase activity (LPO) after LPS challenge

\begin{tabular}{lcc}
\hline Item & Time of increase $^{1}(\mathrm{~h})$ & Time of decrease $^{2}(\mathrm{~d})$ \\
\hline SCC & $2.8 \pm 0.3^{\mathrm{a}}$ & $4.8 \pm 0.5^{\mathrm{a}}$ \\
LAP & $3.2 \pm 0.5^{\mathrm{a}}$ & $1.5 \pm 0.3^{\mathrm{b}}$ \\
LPO & $5.5 \pm 0.4^{\mathrm{b}}$ & $2.9 \pm 0.3^{\mathrm{c}}$ \\
\hline
\end{tabular}

${ }^{\mathrm{a}-\mathrm{c}}$ Values within a column with different letters are significantly different $(P<0.05)$.

${ }^{1}$ Time when values showed $>500 \times 10^{3}$ cell $/ \mathrm{mL}$ (SCC), $10 \mathrm{nM}$ (LAP), or $5 \mathrm{U}$ (LPO) for the first time.

${ }^{2}$ Time when values decreased $<500 \times 10^{3}$ cell $/ \mathrm{mL}$ (SCC), $10 \mathrm{nM}$ (LAP), or $5 \mathrm{U}$ (LPO) following high values. 


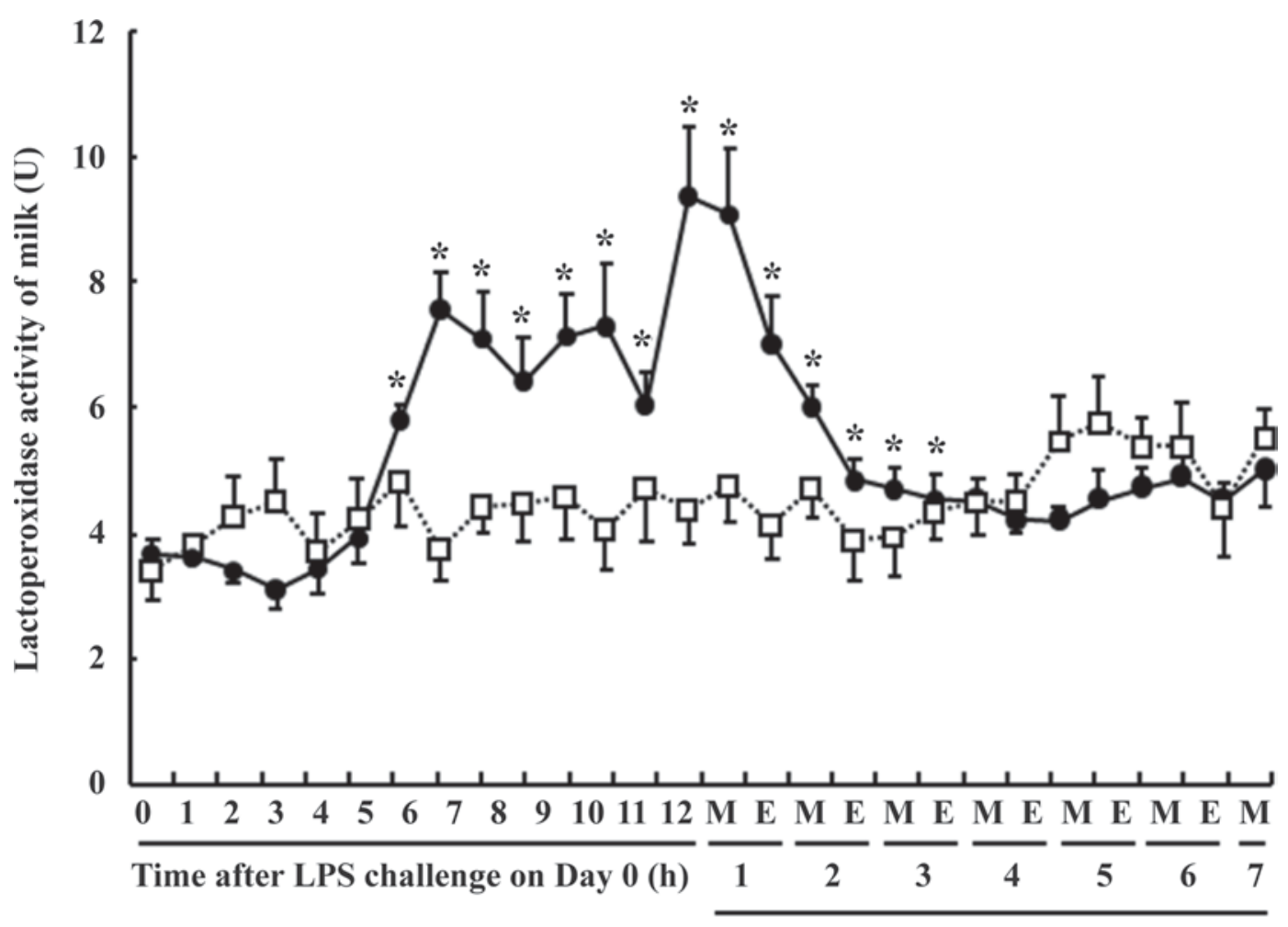

Day after LPS challenge

Figure 3. Lactoperoxidase activity in milk after LPS $(\bullet)$ or PBS $(\square)$ infusion in dairy cows. Values are expressed as mean \pm SEM. ${ }^{*}$ Indicates that concentrations are higher $(P<0.05)$ than that before LPS infusion. $\mathrm{M}=$ morning; $\mathrm{E}=$ evening.

tained until d 3, suggesting that LPS induced active LPO secretion into milk. Immunohistochemical studies revealed that LPO was synthesized in the alveolar epithelium (Harada et al., 1973), suggesting that LPO in the milk must be derived from the alveolar epithelium. Myeloperoxidase was found in the neutrophils in the milk (Cooray, 1994), but in the present study neutrophils were removed by centrifugation before LPO activity determination. So far, no other types of peroxidase have been found in bovine milk. Therefore, LPO activity in the present study is possibly attributable only to LPO.

Lactoperoxidase activity increased at $6 \mathrm{~h}$ and declined by $\mathrm{d} 4$, although LAP concentration increased at $2 \mathrm{~h}$ and declined by $\mathrm{d} 3$, indicating a delay of LPO activity initiation and cessation in the milk compared with LAP. Both LAP and LPO are secreted by the alveolar epithelium. Therefore, different secretory mechanisms may exist for LAP and LPO in the alveolar epithelium. Further, when correlation between LAP and LPO was examined, there was a significantly negative correlation between time points of LAP and LPO decline $(\mathrm{r}=$ $-0.75)$. This indicated that the earlier the LAP concentration decreases, the later the LPO activity decreases, suggesting that LPO may be secreted in complementary action against LAP.

Clinical mastitis is caused by environmental bacteria such as E. coli that have an LPS component in the cell membrane. In the present study, LPS infusion caused an increase in the milk LAP concentration. Therefore, clinical mastitis stimulates secretion of LAP into milk, suggesting that LAP plays an important role in preventing mastitis in dairy cows. This finding has important immunological implications toward controlling the problem of mastitis in the dairy industry.

\section{ACKNOWLEDGMENTS}

We thank Lawrence M. Liao, Graduate School of Biosphere Science, Hiroshima University (HigashiHiroshima, Japan) for his critical reading of our manuscript.

\section{REFERENCES}

Bosch, E. H., H. van Doorne, and S. de Vries. 2000. The lactoperoxidase system: The influence of iodide and the chemical and antimicrobial stability over the period of about 18 months. J. Appl. Microbiol. $89: 215-224$. 
Cooray, R. 1994. Use of bovine myeloperoxidase as an indicator of mastitis in dairy cattle. Vet. Microbiol. 42:317-326.

Diamond, G., M. Zasloff, H. Eck, M. Brasseur, W. L. Maloy, and C. L. Bevins. 1991. Tracheal antimicrobial peptide, a cysteine-rich peptide from mammalian tracheal mucosa: Peptide isolation and cloning of a cDNA. Proc. Natl. Acad. Sci. USA 88:3952-3956.

Fonteh, F. A., A. S. Grandison, and M. J. Lewis. 2002. Variations of lactoperoxidase activity and thiocyanate content in cows' and goats' milk throughout lactation. J. Dairy Res. 69:401-409.

Fweja, L. W. T., M. J. Lewis, and A. S. Grandison. 2007. Alternative strategies for activation of the natural lactoperoxidase system in cows' milk: Trials in Tanzania. J. Dairy Res. 74:381-386.

Ganz, T. 2003. Defensins: Antimicrobial peptides of innate immunity. Nat. Rev. Immunol. 3:710-720.

Goldammer, T., H. Zerbe, A. Molenaar, H. J. Schuberth, R. M. Brunner, S. R. Kata, and H. M. Seyfert. 2004. Mastitis increases mammary mRNA abundance of $\beta$-defensin 5 , toll-like-receptor 2 (TLR2), and TLR4 but not TLR9 in cattle. Clin. Diagn. Lab. Immunol. 11:174-185.

Harada, T., M. Baba, and S. Morikawa. 1973. Immunohistochemical localization of lactoperoxidase in bovine tissues. J. Histochem. Cytochem. 21:804-811.

Hoshino, K., O. Takeuchi, T. Kawai, H. Sanjo, T. Ogawa, Y. Takeda, K. Takeda, and S. Akira. 1999. Toll-like receptor 4 (TLR4)-deficient mice are hyporesponsive to lipopolysaccharide: Evidence for TLR 4 as the LPS gene product. J. Immunol. 162:3749-3752.

Isobe, N., K. Hosoda, and Y. Yoshimura. 2009b. Immunolocalization of lingual antimicrobial peptide (LAP) in the bovine mammary gland. Anim. Sci. J. 80:446-450.

Isobe, N., J. Nakamura, H. Nakano, and Y. Yoshimura. 2009a. Existence of functional lingual antimicrobial peptide in bovine milk. J. Dairy Sci. 92:2691-2695.

Marshall, V. M. E., W. M. Cole, and A. J. Bramley. 1986. Influence of the lactoperoxidase system on susceptibility of the udder to Streptococcus uberis infection. J. Dairy Res. 53:507-514

Petzl, W., H. Zerbe, J. Günther, W. Yang, H. M. Seyfert, G. Nürnberg, and H. J. Schuberth. 2008. Escherichia coli, but not Staphylococcus aureus, triggers an early increased expression of factors contributing to the innate immune defense in the udder of the cow. Vet. Res. 39:18.
Schalm, O. W., E. J. Carroll, and N. C. Jain. 1971. Number and types of somatic cells in normal and mastitic milk. Pages 94-127 in Bovine Mastitis. 1st ed. O. W. Schalm, E. J. Carroll, and N. C. Jain, ed. Lea and Febiger, Philadelphia, PA.

Schonwetter, B. S., E. D. Stolzenberg, and M. A. Zasloff. 1995. Epithelial antibiotics induced at sites of inflammation. Science 267:1645-1648.

Seifu, E., E. F. Donkinb, and E. M. Buysc. 2007. Potential of lactoperoxidase to diagnose subclinical mastitis in goats. Small Rumin. Res. 69:154-158.

Selsted, M. E., Y. Q. Tang, W. L. Morris, P. A. McGuire, M. J Novotny, W. Smith, A. H. Henschen, and J. S. Cullor. 1993. Purification, primary structures, and antibacterial activities of $\beta$-defensins, a new family of antimicrobial peptides from bovine neutrophils. J. Biol. Chem. 268:6641-6648.

Shin. K., H. Hayasawa, and B. Lönnerdal. 2001. Inhibition of Escherichia coli respiratory enzymes by the lactoperoxidasehydrogen peroxide-thiocyanate antimicrobial system. J. Appl. Microbiol. 90:489-493.

Subedi, K., N. Isobe, and Y. Yoshimura. 2008. Changes in the localization of immunoreactive avian $\beta$-defensin-12 in ovarian follicles during follicular growth and in response to lipopolysaccharide. Jpn. Poult. Sci. 45:210-214.

Swanson, K., S. Gorodetsky, L. Good, S. Davis, D. Musgrave, K. Stelwagen, V. Farr, and A. Molenaar. 2004. Expression of a $\beta$-defensin mRNA, lingual antimicrobial peptide, in bovine mammary epithelial tissue is induced by mastitis. Infect. Immun. 72:7311-7314

Tarver, A. P., D. P. Clark, G. Diamond, J. P. Russell, H. ErdjumentBromage, P. Tempst, K. S. Cohen, D. E. Jones, R. W. Sweeney, M. Wines, S. Hwang, and C. L. Bevins. 1998. Enteric $\beta$-defensin: molecular cloning and characterization of a gene with inducible intestinal epithelial cell expression associated with Cryptosporidium parvum infection. Infect. Immun. 66:1045-1056.

Wijkstrom-Frei, C., S. El-Chemaly, R. Ali-Rachedi, C. Gerson, M. A. Cobas, R. Forteza, M. Salathe, and G. E. Conner. 2003. Lactoperoxidase and human airway host defense. Am. J. Respir. Cell Mol. Biol. 29:206-212. 